\title{
Global transcriptomic response of bovine endometrium to blastocyst-stage embryos
}

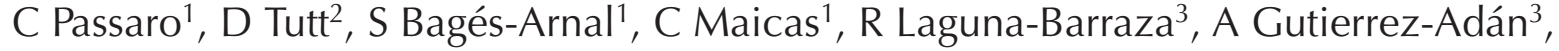 \\ J A Browne ${ }^{1}$, D Rath ${ }^{4}$, S K Behura ${ }^{5}$, T E Spencer ${ }^{5}$, T Fair ${ }^{1}$ and P Lonergan ${ }^{1}$ \\ ${ }^{1}$ School of Agriculture and Food Science, University College Dublin, Belfield, Dublin 4, Ireland, ${ }^{2}$ School of \\ Veterinary Science, The University of Queensland, Gatton, Queensland, Australia, ${ }^{3}$ Departamento de Reproducción \\ Animal, Instituto Nacional de Investigación y Tecnología Agraria y Alimentaria, Madrid, Spain, ${ }^{4}$ Institute of Farm \\ Animal Genetics, Friedrich-Loeffler-Institut, Neustadt-Mariensee, Germany and ${ }^{5}$ Division of Animal Sciences, \\ University of Missouri, Columbia, Missouri, USA
}

Correspondence should be addressed to P Lonergan; Email: pat.lonergan@ucd.ie

\begin{abstract}
The aims of this study were (i) to investigate changes in the global transcriptome of bovine endometrial explants induced by exposure to blastocysts, (ii) to investigate if male and female blastocysts elicit a differential response in the endometrial transcriptome in vitro and (iii) to determine whether bovine endometrium responds to the presence of murine embryos. In Experiment 1, endometrial explants from the same uterus were cultured for $6 \mathrm{~h}$ with or without 20 in vitro-produced bovine blastocysts. In Experiment 2 , endometrial explants were cultured with male or female bovine blastocysts produced in vitro by IVF either using sex-sorted semen or conventional unsorted semen followed by embryo sexing based on a biopsy. In Experiment 3, endometrial explants were cultured alone or in the presence of bovine blastocysts $(n=25)$ or murine blastocysts $(n=25)$. Following culture, explants were snap frozen and stored at $-80^{\circ} \mathrm{C}$ until RNA extraction, qPCR or RNA-Seq. Culture with bovine blastocysts increased endometrial expression of 40 transcripts, all of which were interferon-tau induced. Culture with male or female bovine blastocysts increased transcript abundance of five classic interferon-stimulated genes (MX1, MX2, ISG15, OASY1, RSAD2) in explants; however, there was no difference in abundance of transcripts previously reported to be related to embryonic sex (IFNAR1, IFNAR2, CTGF, ARTN, SLC2A1, SLC2A5). Exposure to murine blastocysts did not elicit any detectable change in transcript abundance. These findings, coupled with our previous data, indicate that very local, interferon-tau-induced changes in endometrial gene expression occur in response to blastocysts; whether such changes play any role in subsequent pregnancy recognition remains to be established.

Reproduction (2019) 158 223-235
\end{abstract}

\section{Introduction}

Following hatching of the ruminant blastocyst, communication between the elongating conceptus and the maternal endometrium is essential for maternal recognition of pregnancy, prevention of luteolysis and maintenance of progesterone secretion from the corpus luteum. Partly due to its minute size, communication between the pre-hatching, zona-enclosed embryo and the endometrium is more challenging to demonstrate and is apparently not essential for pregnancy establishment, as evidenced by the fact that pregnancies are established after embryo transfer to a uterus not previously exposed to an embryo.

There are very few, if any, global transcriptomic data sets available highlighting alterations in transcript abundance induced in the endometrium by the presence of a blastocyst(s). Indeed, many such studies carried out in vivo, including some of our own work (Forde et al. 2011) and that of others (Bauersachs et al. 2012), have failed to identify changes in the endometrial transcriptome prior to Day $15 / 16$, by which time the elongated conceptus is secreting copious amounts of IFNT.

Using qRT-PCR, we have recently shown that bovine endometrial explants respond to the presence of 8-day-old blastocysts by upregulating the expression of classical interferon-stimulated genes (ISG) (Passaro et al. 2018). This effect was (i) specific to the blastocyst stage - earlier stages did not induce gene expression changes, (ii) dependent on the number of blastocysts present - a minimum of five blastocysts were required to detect such changes and (iii) independent of direct contact - the effect was induced by embryos co-cultured on endometrial explants using a cell culture insert (preventing direct contact) as well as by blastocyst-conditioned medium (Passaro et al. 2018). Others have reported differential expression of a small number of other transcripts in the endometrium in vivo, induced by the presence of a single blastocyst 
(Sponchiado et al. 2017) or in cultured endometrial cells (Talukder et al. 2017, Gómez et al. 2018a), which we failed to detect in endometrial explants using qPCR (Passaro et al. 2018).

A significant volume of evidence suggests that preimplantation embryo development (BermejoAlvarez et al. 2010a), metabolism (Tiffin et al. 1991, Gómez et al. 2018b) and gene expression (BermejoAlvarez et al. 2010a) are influenced by the sex of the embryo and development during this period can be further exacerbated by environmental (Hansen et al. 2016) and culture conditions (Larson et al. 2001). Male bovine embryos have been reported to develop faster (Avery et al. 1992) and reach the blastocyst stage more frequently (Xu et al. 1992) than female embryos. Indeed, bovine female in vitro-fertilized blastocysts display lower cell numbers and increased apoptosis than their male counterparts (Oliveira et al. 2010). Gómez et al. (2013) reported differential protein expression in Day 8 uterine fluid recovered from heifers following the transfer of Day 5 male or female embryos. More recently, Gómez et al. (2018a) described an embryo sex-dependent response of cultured bovine uterine epithelial (but not stromal) cells, suggesting that male and female embryos may differentially release signalling factors that induce sexually dimorphic responses in such cells.

Implantation in ruminants differs from that of rodents and primates where the conceptus enters a receptive uterus, hatches and almost immediately attaches to the uterine luminal epithelium (haemochorial placentation) (Cha \& Dey 2015, Su \& Fazleabas 2015). In contrast, the ruminant conceptus remains unattached for almost 3 weeks prior to implantation, during which time it rapidly elongates prior to implantation (synepitheliochorial placentation) (Lonergan \& Forde 2014, Spencer et al. 2016). Elongation in ruminant embryos is a maternally driven process - it has not been successfully recapitulated in vitro (Brandão et al. 2004, Alexopoulos et al. 2005) and does not occur in vivo in the absence of uterine glands and associated secretions (Gray et al. 2002). However, whether the ruminant embryo is intrinsically programmed to elongate or whether this is exclusively driven by the maternal uterine environment is not known. Evidence for a component intrinsic to the embryo comes from the significant variation in the size of age-matched conceptuses (Betteridge et al. 1980), even among those recovered from the same uterus following embryo transfer (Clemente et al. 2009, Sánchez et al. 2019). Such variation in conceptus length is also evident in porcine conceptuses, despite growing in a common uterine environment, and rapid progression through this phase has been associated with conceptus competency (Blomberg et al. 2010).

Here, we used an endometrial explant-embryo co-culture model to elucidate the fine dialogue between the early conceptus and endometrium. Endometrial explants maintain normal cellular and extracellular architecture and allow for communication between resident populations of endometrial cells which cannot be achieved using a 2D culture system. To extend our previous findings, the aims of this study were (i) to investigate changes in the global transcriptome of endometrial explants induced by exposure to blastocysts using RNA sequencing (RNA-Seq), (ii) to investigate if male and female blastocysts elicit a differential response in the endometrial transcriptome in vitro and (iii) to determine whether the bovine endometrium responds to the presence of murine embryos, which do not exhibit post-hatching elongation prior to implantation.

\section{Materials and methods}

Unless otherwise stated, all chemicals were sourced from Sigma-Aldrich.

\section{Experiment 1: Global transcriptome analysis of endometrial response to bovine blastocysts}

The aim of this experiment was to interrogate the global transcriptomic response of the bovine endometrium to the presence of blastocysts. Endometrial explants from the same uterus were cultured for $6 \mathrm{~h}$ with medium alone (control) or with 20 Day 8 in vitro-produced blastocysts using a polyester mesh to retain the embryos directly above the endometrial surface as recently described (Passaro et al. 2018). Five replicates (i.e. explants from five different uteri) were carried out. After incubation, explants were snap frozen and stored at $-80^{\circ} \mathrm{C}$ until RNA extraction and RNA-Seq analysis.

\section{Experiment 2: Endometrial response to male and female blastocysts}

To investigate the transcriptomic response of the endometrium to the presence of male and female embryos, Day 8 blastocysts were produced in vitro by IVF either using (i) sex-sorted (X- or Y-sorted) semen or (ii) conventional unsorted semen followed by embryo sexing based on a biopsy taken on Day 6, as detailed below.

\section{Experiment 2(a): Blastocyst production with sex- sorted semen}

Bovine ovaries were collected at a local abattoir and transported to the laboratory in $\mathrm{PBS}$ at $35^{\circ} \mathrm{C}$ within $4 \mathrm{~h}$. Cumulus-oocytes complexes (COCs) were aspirated from surface visible antral follicles using an 18-gauge needle attached to a $5 \mathrm{~mL}$ syringe. In vitro maturation, fertilization and culture were carried out as previously described (Rizos et al. 2002). Briefly, grade 1 COCs were matured for $24 \mathrm{~h}$ in TCM-199 supplemented with $10 \%$ fetal calf serum (FCS) and $10 \mathrm{ng} / \mathrm{mL}$ epidermal growth factor (EGF) at $38.5^{\circ} \mathrm{C}$ under an atmosphere of $5 \%$ $\mathrm{CO}_{2}$ in air with maximum humidity. Fertilization (Day 0) was performed with $\mathrm{X}$ - or Y-sorted sperm from one of three different bulls, as previously described (Bermejo-Alvarez et al. 2010b). Matured COCs were inseminated with frozen-thawed, 
Percoll-separated, semen added at a final concentration of $2 \times 10^{6} \mathrm{sperm} / \mathrm{mL}$. Gametes were co-incubated at $38.5^{\circ} \mathrm{C}$ in an atmosphere of $5 \% \mathrm{CO}_{2}$ in air with maximum humidity. At approximately $20 \mathrm{~h}$ post-insemination, presumptive zygotes were denuded of surrounding cumulus cells and accessory sperm and cultured in $25 \mu \mathrm{L}$ drop of synthetic oviduct fluid (SOF) supplemented with $5 \%$ FCS until Day 8 at $38.5^{\circ} \mathrm{C}$ in an atmosphere of $5 \% \mathrm{CO}_{2}, 5 \% \mathrm{O}_{2}$ with maximum humidity. On Day 8, blastocysts produced from X-and Y-sorted sperm from each bull were pooled together according to sex in groups of approximately 20 and cultured on endometrial explants for 6 h. Five replicates (i.e., separate days of ovary collection) were conducted. After incubation, explants were snap frozen and stored at $-80^{\circ} \mathrm{C}$ until RNA extraction, reverse transcription and qPCR analysis.

\section{Experiment 2(b): Blastocyst production and sexing by embryo biopsy}

On Day 6 post fertilization, morula stage embryos were biopsied by blastomere extrusion (Tominaga \& Hamada 2004) of three to eight cells for sex identification. After biopsy, embryos were returned to culture until Day 8, when those embryos that reached the blastocyst stage were cultured on an endometrial explant for $6 \mathrm{~h}$ in groups of 12-15 according to sex in a total of four replicates. After incubation, explants were snap frozen and stored at $-80^{\circ} \mathrm{C}$ until RNA extraction, reverse transcription and qPCR analysis.

For Experiments 2(a-b), transcript abundance of genes previously shown by us to be induced in endometrial explants by the presence of blastocysts (MX1, MX2, ISG15, OASY1, RSAD2; Passaro et al. 2018) as well as genes reported by others to be altered by embryos in a sex-specific manner in cultured uterine epithelial cells (IFNAR1, IFNAR2, CTGF, ARTN, SLC2A1, SLC2A5; Gómez et al. 2018a) was investigated.

\section{Experiment 3: Response of bovine endometrium to bovine vs murine blastocysts}

In order to compare the response of bovine endometrium to embryos which intrinsically elongate (bovine) vs those that do not (murine), endometrial explants from the same uterus were cultured: (i) alone (control) or in the presence of (ii) Day 8 bovine blastocysts $(n=25)$ or (iii) murine blastocysts $(n=25)$. Following culture, explants were snap frozen and stored at $-80^{\circ} \mathrm{C}$ until RNA extraction and RNA-Seq analysis. Five replicates were carried out.

To generate murine embryos, B6D2F1 female mice were superovulated by intraperitoneal injection of $7.5 \mathrm{IU}$ equine chorionic gonadotrophin (Folligon 500, Intervet) followed by $7.5 \mathrm{IU}$ hCG (Veterin Corion, Equinvest) $48 \mathrm{~h}$ later. On the night of the hCG injection, females were mated with males. Presence of a vaginal plug the next morning was designated as Day 0.5 postcoitum. Females $(n=17)$ were killed by cervical dislocation on Day 2.5 and embryos were recovered by oviduct flushing. Morula stage embryos $(n=335)$ were cultured in $25 \mu \mathrm{L}$ droplets of $\mathrm{K}^{+}$-modified simplex optimized medium (KSOM; Millipore) under mineral oil until Day 4.
Dishes were incubated at $37^{\circ} \mathrm{C}$ in a humidified atmosphere of $5 \% \mathrm{CO}_{2}$ in air.

\section{Embryo sexing by PCR}

In Experiment 2, PCR was used to identify embryonic sex from entire embryos following explant co-culture (Experiment 2a) and from biopsy samples (Experiment 2b), to verify the accuracy of embryo sex selection. Briefly, two primer sets were used to determine embryo sex: Y-chromosome-specific primers (TSPY, 5' GGTACACAAGAGCAGCGTTC forward, 5' GAGGGTGGCATAATCTGCTT reverse, $535 \mathrm{bp}$ amplicon) and bovine-specific satellite sequence primers (Park et al. 2001) (Sat 1.715, 5' TGGAAGCAAAGAACCCCGCT forward, 5' TCGTGAGAAACCGCACACTG reverse, $216 \mathrm{bp}$ amplicon). Samples were thawed, boiled at $100^{\circ} \mathrm{C}$ for $10 \mathrm{~min}$, and then held on ice. PCR reaction mix $(45 \mu \mathrm{L})$, consisting of Dream Taq Green Master Mix (Thermo Fisher Scientific) and the primer set for TSPY (1 $\mu \mathrm{M}$ final concentration) was added and the tube transferred to the thermocycler. The PCR programme used an initial denaturation step at $95^{\circ} \mathrm{C}$ for $3 \mathrm{~min}$, and then TSPY was pre-amplified for ten cycles of $95^{\circ} \mathrm{C}$ for $30 \mathrm{~s}, 60^{\circ} \mathrm{C}$ for $45 \mathrm{~s}$, $72^{\circ} \mathrm{C}$ for $50 \mathrm{~s}$. After ten cycles, the tubes were held at $4^{\circ} \mathrm{C}$ while the primer set for satellite $1.715(1 \mu \mathrm{M}$ final concentration) was added, and then returned to the thermocycler for another 35 cycles on the same programme. A final extension step at $72^{\circ} \mathrm{C}$ for $5 \mathrm{~min}$ was included at the end of 35 cycles. Products were visualized on an ethidium bromide-stained $2 \%$ agarose gel under ultraviolet illumination for the positive $534 \mathrm{bp}$ band of TSPY and $216 \mathrm{bp}$ of the satellite sequence. Samples that exhibited both bands were assigned as male, while samples exhibiting only a satellite sequence band were assigned as female. Each PCR was carried out with three controls: negative (no template) control, female genomic DNA, male genomic DNA (Fig. 1).

\section{Endometrial explant preparation}

Bovine uteri from females estimated to be between Day 5 and 10 of the oestrous cycle based on ovarian morphology (Ireland et al. 1980) were collected at a local abattoir from post-pubertal non-pregnant heifers. Uteri were transported to the laboratory on ice and processed as described previously (Passaro et al. 2018). Briefly, the external surfaces of the uterus were washed in $70 \%$ ethanol and the uterine horn ipsilateral to the corpus luteum was opened longitudinally with sterile scissors. The exposed endometrium was washed in Dulbecco's PBS supplemented with $100 \mathrm{IU} / \mathrm{mL}$ penicillin, $100 \mu \mathrm{g} / \mathrm{mL}$ streptomycin and $0.25 \mu \mathrm{g} / \mathrm{mL}$ amphotericin B. Tissue was collected from the intercaruncular areas of the endometrium from the distal part of the uterine horn (upper third) ipsilateral to the corpus luteum using a sterile 4-mm-diameter biopsy punch (Stiefel Laboratories Ltd, High Wycome, UK). Each explant was immediately transferred to Hank's Balanced Salt Solution (HBSS) supplemented with $100 \mathrm{IU} / \mathrm{mL}$ penicillin, $100 \mu \mathrm{g} / \mathrm{mL}$ streptomycin and $0.25 \mu \mathrm{g} / \mathrm{mL}$ amphotericin B, before washing twice in unsupplemented HBSS. Under sterile conditions within a class II biological safety cabinet, explants were transferred to 24 -well plate, so that each well contained 


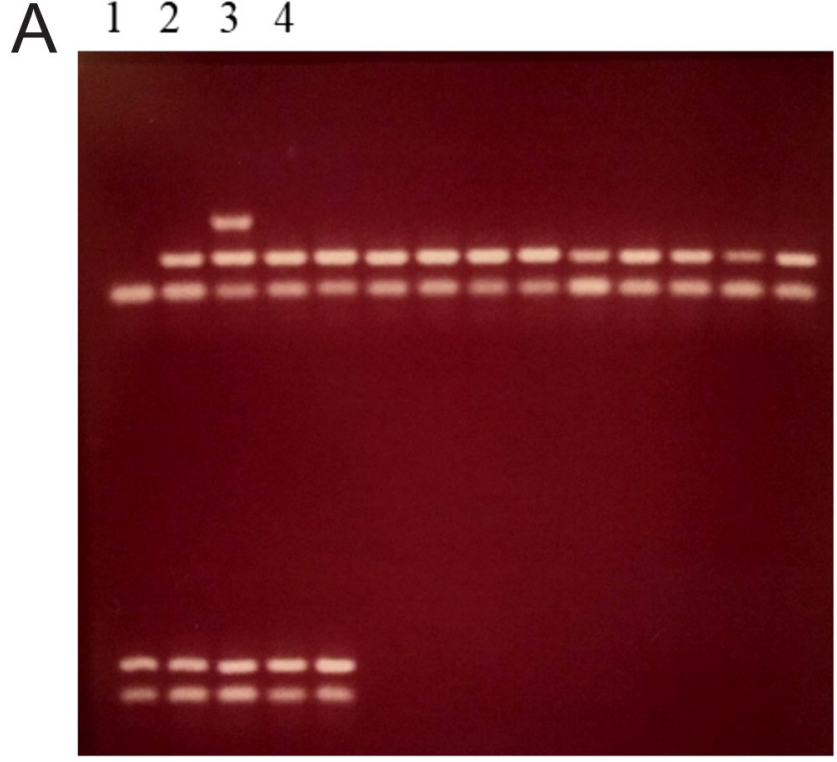

Female embryos

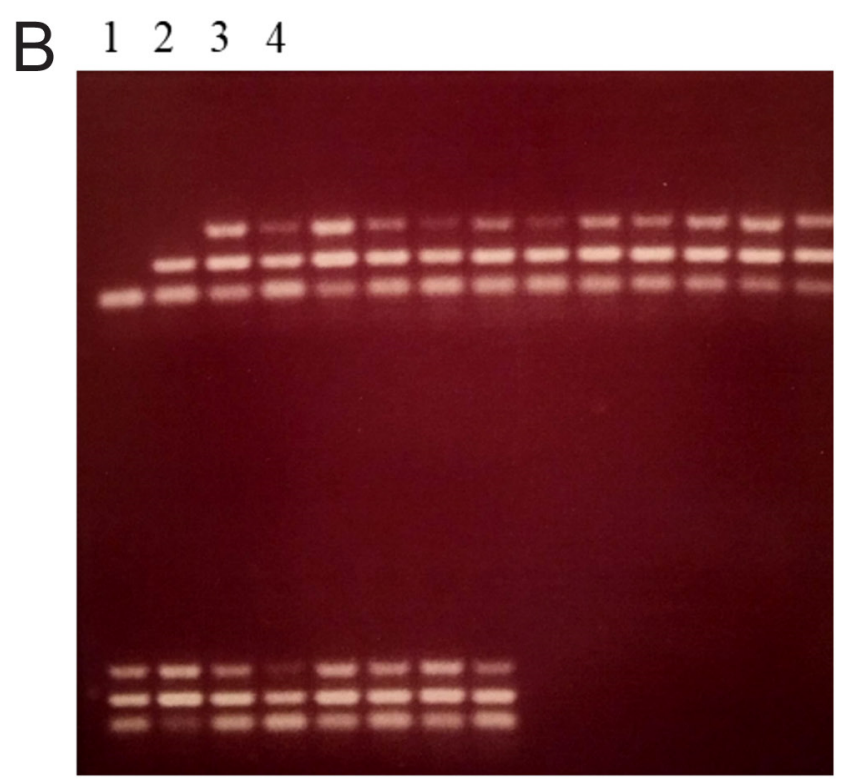

Male embryos

Figure 1 Representative gels from embryo sexing by PCR. A single PCR using both Y-chromosome-specific primers (TSPY) and bovinespecific satellite sequence primers (Sat 1.715) was carried out. Lane 1: No template control. Lane 2: female gDNA. Lane 3: male gDNA. (A) From Lane 4 on: female embryos with a 216 bp specific product of Sat. (B) From lane 4 on: male embryos, a 535 bp Y-chromosomespecific product (TSPY) appears in the top lane.

a single explant in $1.0 \mathrm{~mL}$ of complete medium. Complete medium comprised Roswell Park Memorial Institute medium (RPMI 1640), supplemented with $100 \mathrm{IU} / \mathrm{mL}$ penicillin, $100 \mu \mathrm{g} / \mathrm{mL}$ streptomycin and $0.25 \mu \mathrm{g} / \mathrm{mL}$ amphotericin B. The explants of intact endometrium were orientated with the
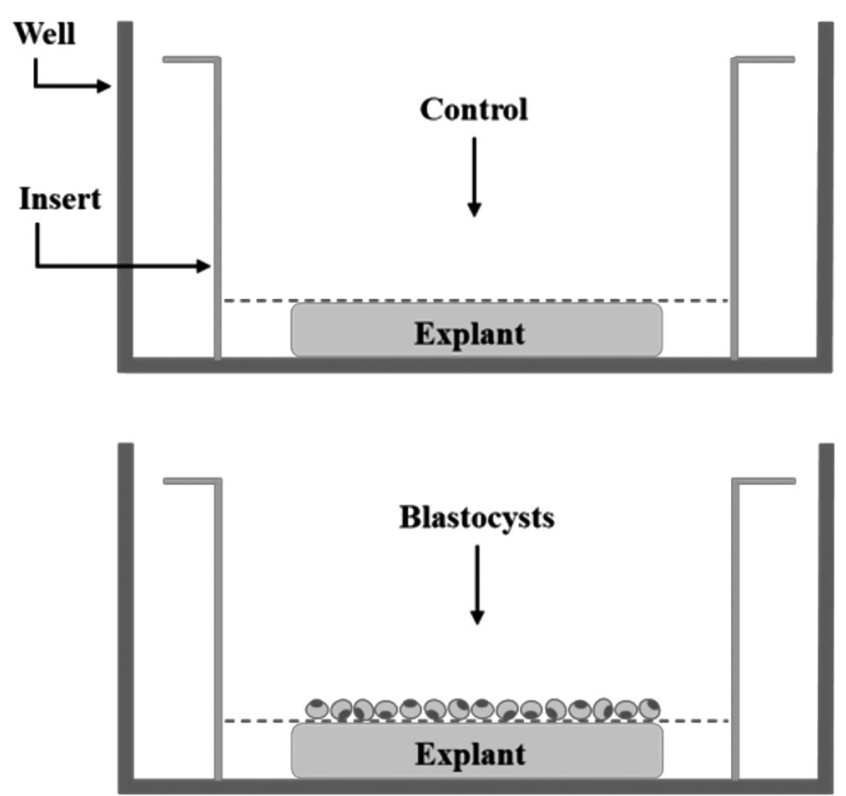

Figure 2 Representation of endometrial explant with cell culture insert used to retain in vitro-produced Day 8 blastocysts during co-culture.

epithelial surface uppermost and cultured in a humidified atmosphere with $5 \% \mathrm{CO}_{2}$ in air at $38.5^{\circ} \mathrm{C}$. The culture medium was changed twice (every $2 \mathrm{~h}$ ) before applying the specific treatment, according to the experimental design.

Apart from Experiment 1, in which a polyester mesh was used, cell culture inserts with a $12 \mu \mathrm{M}$ pore size (MILLICELLPCF $12.0 \mu \mathrm{M}$, Catalogue Number PIX01250, Millipore) were used during the $6 \mathrm{~h}$ co-culture to ensure the embryos were maintained directly above the endometrial surface (Fig. 2). A control explant (insert without embryos) was included in each replicate. To mitigate against potential variation, in each experiment, within a replicate (i.e. on a given day), each treatment was applied to explants from the same uterus, and this was replicated across multiple animals.

\section{RNA extraction and CDNA synthesis}

Total RNA was isolated using TRIzol reagent (Molecular Research Center) as per the manufacturer's instructions followed by on-column RNA clean-up using the Qiagen RNeasy mini kit (Qiagen). Briefly, $30 \mathrm{mg}$ of tissue was homogenized in $1.0 \mathrm{~mL}$ of TRIzol using a steel bead and the Qiagen tissue lyzer $(2 \times 120 \mathrm{~s}$ at maximum speed). After homogenization, $100 \mu \mathrm{L}$ of 1-Bromo-3-chloro-propane was added to each sample. Following centrifugation $(12,000 \mathrm{~g}, 15 \mathrm{~min})$, the upper aqueous phase was transferred directly into a RNeasy column and RNA was purified as per the manufacturer's instruction. RNA was quantified using a NanoDrop-ND1000 Spectrophotometer (Thermo Fisher Scientific).

In Experiment 2 (a-b), for each sample, cDNA was prepared from $500 \mathrm{ng}$ of total RNA using the High-Capacity cDNA Reverse Transcription Kit (Thermo Fisher Scientific) according to the manufacturer's instructions. The purified cDNA was then 
diluted in RNase- and DNase-free water up to a volume of $300 \mu \mathrm{L}$ and stored at $-20^{\circ} \mathrm{C}$ for subsequent use.

\section{RNA-Seq analysis}

In Experiments 1 and 3, RNA was extracted from endometrial explants following 6-h culture. Quantity and quality of RNA were determined using the Nano Drop 1000 (Thermo Fisher Scientific) and the Agilent Bioanalyzer (Agilent Technologies), respectively. The mean RNA integrity number $(\mathrm{RIN}) \pm$ the standard deviation was $7.4 \pm 0.4$ for experiment 1 and $7.6 \pm 0.4$ for Experiment 3. RNA library preparation and sequencing and RNA-Seq data mapping and quantification of read counts for genes were performed as described previously (Moraes et al. 2018). The differential gene expression analysis was performed by edger- $\mathrm{R}$ robust (Zhou et al. 2014).

\section{Pathway and process enrichment analysis}

Pathway and process enrichment analysis was carried out with using Metascape (http://metascape.org), an online gene annotation and analysis resource. All genes in the genome were used as the enrichment background. Terms with a $P$ value $<0.01$, a minimum count of 3 and an enrichment factor $>1.5$ (the ratio between the observed counts and the counts expected by chance) are collected and grouped into clusters based on their membership similarities. More specifically, $P$ values were calculated based on the accumulative hypergeometric distribution (Zar 1999), and $q$ values were calculated using the Benjamini-Hochberg procedure to account for multiple testing (Hochberg \& Benjamini 1990). Kappa scores (Cohen 1960) were used as the similarity metric when performing hierachical clustering on the enriched terms, and sub-trees with a similarity of $>0.3$ were considered a cluster. The most statistically significant term within a cluster is chosen to represent the cluster.

\section{qPCR analysis of candidate genes}

In Experiment 2 (a-b), qPCR was used to investigate changes in endometrial gene expression due to the presence of male or female embryos, as previously described (Passaro et al. 2018). Unless otherwise specified, all primers were designed using Primer-Blast software (https://www.ncbi.nlm.nih.gov/tools/ primer-blast/) (Table 1). A total of eight potential reference genes (GAPDH, ACTB, RPL18, PPIA, YWHAZ, RNF11, $H 3 F 3 A, S D H A)$ were analysed using the geNorm function within the qbase+ computer program (Biogazelle, Zwijnaarde, Belgium). For each independent sample set, geNorm was used to identify the best reference genes (Vandesompele et al. 2002). For Experiment 2(a), ACTB and YWHAZ were shown to be the most stably expressed (average geNorm $M \leq 0.5$ ), while for Experiment 2(b), H3F3A and YWHAZ were the most stably expressed. Gene expression analysis was carried out for the following genes: MX1, MX2, ISG15, OASY1, RSAD2, IFNAR1, IFNAR2, CTGF, ARTN, SLC2A1, SLC2A5. For Experiment $2(a-b)$, one-way ANOVA was performed on the log transformed data.

Table 1 Gene abbreviation, accession number, primers sequence and reference for all genes analysed with qPCR.

\begin{tabular}{|c|c|c|c|c|}
\hline Entrez gene symbol & Accession number & Primer sequence $\left(5^{\prime}-3^{\prime}\right)$ & Fragment size (bp) & Reference \\
\hline YWHAZ & NM_174814.2 & $\begin{array}{l}\text { TGAAGCCATTGCTGAACTTG } \\
\text { TCTCCTTGGGTATCCGATGT }\end{array}$ & 114 & This study \\
\hline H3F3A & NM_001014389.2 & $\begin{array}{l}\text { CATGGCTCGTACAAAGCAGA } \\
\text { ACCAGGCCTGTAACGATGAG }\end{array}$ & 136 & This study \\
\hline$A C T B$ & NM_173979.3 & $\begin{array}{l}\text { CAGCAGATGTGGATCAGCAAGC } \\
\text { AACGCAGCTAACAGTCCGCC }\end{array}$ & 91 & This study \\
\hline$M \times 1$ & NM_173940.2 & $\begin{array}{l}\text { CGAGCCGAGTTCTCCAAATG } \\
\text { CAАСTCTСTGCСАCGАTACC }\end{array}$ & 114 & Passaro et al. 2018 \\
\hline$M \times 2$ & NM_173941.2 & $\begin{array}{l}\text { ACTTTCAAGGACACAGCCAA } \\
\text { АCСАGСТTСTCСАTССTGAA }\end{array}$ & 146 & Passaro et al. 2018 \\
\hline ISG15 & NM_174366.1 & $\begin{array}{l}\text { CСАACСАGTGTCTGCAGAGA } \\
\text { СССТАGСАТTСТСАССGTCA }\end{array}$ & 76 & Passaro et al. 2018 \\
\hline OASY1 & NM_001040606.1 & $\begin{array}{l}\text { CCCGGCGGACCСТACAGGAA } \\
\text { TCCAGCCAGACСАAAGCCGC }\end{array}$ & 84 & Forde et al. 2011 \\
\hline RSAD2 & NM_001045941.1 & $\begin{array}{l}\text { AACAGATAACCGCGCTCAAC } \\
\text { CTTCAAACTCCTCGTCGCTG }\end{array}$ & 129 & Passaro et al. 2018 \\
\hline INFAR1 & NM_174552.2 & $\begin{array}{l}\text { АССТCСTTCСТCTGTTGACG } \\
\text { АCАTCTTTCCGTTTGTTCCTCA }\end{array}$ & 88 & Passaro et al. 2018 \\
\hline INFAR2 & NM_174553.2 & $\begin{array}{l}\text { CTGGTCATTTGTATGGGCTCTTT } \\
\text { GTATCCCGGGACTGTCGAATT }\end{array}$ & 128 & Sponchiado et al. 2017 \\
\hline CTGF & NM_174030.2 & $\begin{array}{l}\text { CACCCGGGTTACCAATGACA } \\
\text { TTGGAGATTTTGGGGGTCCG }\end{array}$ & 138 & This paper \\
\hline$A R T N$ & XM_002686516.2 & $\begin{array}{l}\text { AGAGAACCCAGCAGTGTGAG } \\
\text { AGGCACTTCGGCAACGAAT }\end{array}$ & 89 & Gómez et al. 2018a \\
\hline$S L C 2 A 1$ & NM_174602.2 & $\begin{array}{l}\text { ССТGGGGСТСТTTССТTCAG } \\
\text { CTGGAGCСGTTAGTGTCСTG }\end{array}$ & 66 & This paper \\
\hline SLC2A5 & NM_001101042.2 & $\begin{array}{l}\text { ACCATCGGAATCCTTGTGGC } \\
\text { GGGATCCCAGTCAATCCGAG }\end{array}$ & 95 & This paper \\
\hline
\end{tabular}




\section{Results}

\section{Experiment 1: Global transcriptome analysis of endometrial response to bovine blastocysts}

Analysis of the RNA-Seq data resulted in the identification of 63 differentially expressed transcripts (61 upregulated and 2 downregulated) in endometrial explants exposed to 20 Day 8 blastocysts for $6 \mathrm{~h}$ compared to control explants ( $\mathrm{P} \leq 0.001$; Table 2 and Supplementary Table 1, see section on supplementary data given at the end of this article). The most highly upregulated transcripts included RSAD2, OAS1Y, IFI44, MX1, MX2, USP18 and ISG15. Pathway and process enrichment analysis showed that Gene Ontologies (GO) associated with specific biological processes such as defence response to virus (GO:0051607), regulation of multi-organism process (GO:0043900) and regulation of type I interferon production (GO:0032479) are significantly enriched by the differentially expressed genes. In addition, we also identified specific Reactome Gene Sets associated with Interferon Signalling (R-HSA-913531) and ISG15 antiviral mechanism (R-HSA-1169408) are also significantly enriched (Table 3).

\section{Experiment 2: Endometrial response to male and female blastocysts}

In vitro development of bovine embryos produced using sex-sorted sperm

Embryo development following IVF with X-and Y-sorted sperm from each bull is shown in Table 4. Cleavage was assessed at $48 \mathrm{~h}$ post insemination and blastocyst yield was recorded on Day 8. Overall, while cleavage rates were not different, IVF with $\mathrm{X}$-sorted sperm resulted in lower $(P<0.05)$ blastocyst development $(8.4 \pm 2.9 \%)$ than insemination with Y-sorted sperm $(20.6 \pm 2.8 \%)$.

Sex ratio of Day 8 blastocysts

Day 8 blastocysts selected for explant culture as either male or female were predominantly of the correct sex; however, as expected, there were some inaccuracies from embryos produced with sex-sorted sperm (Table 5) and from sexing of biopsy samples (Table 6). In Experiment $2 \mathrm{a}$, over the five replicates, $80.2 \%$ of the blastocysts selected as male, based on IVF with Y-sorted semen, were male and $94.1 \%$ of the blastocysts selected as female, based on IVF with Y-sorted semen, were female. In Experiment 2b, over the four replicates, $95.8 \%$ of the blastocysts selected as male, based on a biopsy taken at Day 6 , were male and $76.2 \%$ of the blastocysts selected as female were female.

Response of endometrial explants to male or female blastocysts

In Experiment 2a we confirmed our previous data (Passaro et al. 2018) reporting an increase in transcript abundance $(P<0.01)$ for the five classic ISG $(M X 1$, MX2, ISG15, OASY1, RSAD2) in endometrial explants co-cultured with Day 8 blastocysts for $6 \mathrm{~h}$. However, there were no differences related to embryonic sex (Fig. 3A). Similarly, in Experiment $2 \mathrm{~b}$, an increase $(P<0.05)$ in transcript abundance for three of the five ISG (MX1, $M X 2$, ISG 15) was observed following co-culture for $6 \mathrm{~h}$ in the presence of blastocysts; as in Experiment 2a, this was not related to embryonic sex (Fig. 3B). No difference in the relative abundance of IFNAR1, IFNAR2, CTGF, ARTN, SLC2A1, SLC2A5 was observed.

\section{Experiment 3: Response of bovine endometrium to bovine vs murine blastocysts}

Representative images of bovine and murine blastocysts used for co-culture with bovine endometrial explants are shown in Fig. 4. Exposure of a bovine endometrial explants to 25 bovine blastocysts for $6 \mathrm{~h}$ resulted in the upregulation of 24 transcripts (Supplementary Table 2). In contrast, exposure to murine blastocysts did not elicit any detectable change in transcript abundance following RNA-Seq (Supplementary Table 2). Combining the data from Experiments 1 and 3 in terms of response of explants to bovine blastocysts ( $n=10$ replicates) revealed the differential expression of 40 transcripts (Supplementary Table 2). Among the most enriched GO terms were response to type I interferon, regulation of defence response to virus and regulation of response to cytokine stimulus (Supplementary Table 3).

Comparison of the list of differentially expressed genes in bovine endometrial explants following 6-h culture with blastocyst-stage embryos (from the combined analysis of Experiments 1 and 3 in the current study) with the common list of genes altered in endometrial explants following $6 \mathrm{~h}$ culture with $100 \mathrm{ng} /$ $\mathrm{mL}$ interferon-tau (IFNT) or a Day 15 conceptus (from Sánchez et al. 2019) indicated that all the DEG induced in the endometrium by blastocyst-stage embryos are IFNT related (Fig. 5).

\section{Discussion}

The main findings of this study are (i) exposure of bovine endometrium to blastocyst-stage embryos results in the alteration of a number of transcripts, all of which are IFNT related; (ii) the expression of a number of candidate genes in bovine endometrium was not affected by the sex of the blastocyst and (iii) murine embryos did not elicit any detectable transcriptomic response in bovine endometrium following 6-h co-culture.

We recently demonstrated that short-term exposure of endometrial explants to bovine blastocysts (Passaro et al. 2018) altered the expression of classical ISGs. Here, we extended those data by examining the global transcriptome of endometrial explants exposed to blastocysts. Results of Experiment 1 revealed the 
Table 2 Gene symbol, gene description, logarithm of fold change (log FC) of differentially expressed genes in bovine endometrial explants following co-culture with Day 8 blastocysts for $6 \mathrm{~h}$ (Experiment 1).

\begin{tabular}{|c|c|c|c|}
\hline Gene symbol & Gene description & $\log$ FC & DE \\
\hline KCND2 & Potassium voltage-gated channel subfamily D member 2 & 5.76 & UP \\
\hline RSAD2 & Radical S-adenosyl methionine domain containing 2 & 5.61 & UP \\
\hline MX2 & MX dynamin-like GTPase 2 & 5.53 & UP \\
\hline IFI44 & Interferon-induced protein 44 & 5.39 & UP \\
\hline LOC100139670 & Interferon-induced protein with tetratricopeptide repeats 1 & 5.01 & UP \\
\hline IFIT3 & Interferon-induced protein with tetratricopeptide repeats 3 & 4.86 & UP \\
\hline CLEC4F & C-type lectin domain family 4 member $F$ & 4.41 & UP \\
\hline IFI44L & Interferon-induced protein 44 like & 4.34 & UP \\
\hline ISG15 & ISG15 ubiquitin-like modifier & 4.34 & UP \\
\hline OAS1X & $2^{\prime}-5^{\prime}$-Oligoadenylate synthetase $40 / 46 \mathrm{kDa}$ & 3.95 & UP \\
\hline OAS2 & 2'-5'-Oligoadenylate synthetase 2 & 3.80 & UP \\
\hline USP18 & Ubiquitin specific peptidase 18 & 3.77 & UP \\
\hline LOC112441507 & Bone marrow stromal antigen 2-like & 3.74 & UP \\
\hline SAMD9 & Sterile alpha motif domain containing 9 & 3.69 & UP \\
\hline LOC100298356 & Bone marrow stromal antigen 2 & 3.68 & UP \\
\hline MX1 & MX dynamin like GTPase 1 & 3.59 & UP \\
\hline OAS1Y & 2'-5'-Oligoadenylate synthetase 40/46 kDa & 3.57 & UP \\
\hline OAS1Z & 2'-5'-Oligoadenylate synthetase 40/46 kDa & 3.53 & UP \\
\hline IFIT2 & Interferon-induced protein with tetratricopeptide repeats 2 & 3.50 & UP \\
\hline KRT75 & Keratin 75 & 3.46 & UP \\
\hline UBA7 & Ubiquitin-like modifier activating enzyme 7 & 3.46 & UP \\
\hline LOC507055 & Guanylate-binding protein 4 & 3.19 & UP \\
\hline SLFN11 & Schlafen family member 11 & 3.03 & UP \\
\hline ZBP1 & Z-DNA binding protein 1 & 2.97 & UP \\
\hline LOC509283 & E3 ubiquitin protein ligase RNF213 & 2.90 & UP \\
\hline PARP14 & Poly(ADP-ribose) polymerase family member 14 & 2.77 & UP \\
\hline EPSTI1 & Epithelial stromal interaction 1 & 2.77 & UP \\
\hline CMPK2 & Cytidine/uridine monophosphate kinase 2 & 2.65 & UP \\
\hline DDX58 & DExD/H-box helicase 58 & 2.61 & UP \\
\hline CCDC194 & Coiled-coil domain containing 194 & 2.53 & UP \\
\hline IFIH1 & Interferon-induced with helicase $\mathrm{C}$ domain 1 & 2.52 & UP \\
\hline HERC5 & HECT and RLD domain containing E3 ubiquitin protein ligase 5 & 2.45 & UP \\
\hline RTP4 & Receptor transporter protein 4 & 2.45 & UP \\
\hline ZNFX1 & Zinc finger NFX1-type containing 1 & 2.44 & UP \\
\hline BATF2 & Basic leucine zipper ATF-like transcription factor 2 & 2.42 & UP \\
\hline LOC618737 & Bone marrow stromal antigen 2 & 2.40 & UP \\
\hline LOC511531 & Guanylate-binding protein 1 & 2.37 & UP \\
\hline EIF $2 A K 2$ & Eukaryotic translation initiation factor 2 alpha kinase 2 & 2.27 & UP \\
\hline HERC6 & HECT and RLD domain containing E3 ubiquitin protein ligase family member 6 & 2.22 & UP \\
\hline PLAC8 & Placenta-specific 8 & 2.15 & UP \\
\hline IRF9 & Interferon regulatory factor 9 & 2.04 & UP \\
\hline IFI27 & Putative ISG12(a) protein & 1.99 & UP \\
\hline DTX3L & Deltex E3 ubiquitin ligase 3L & 1.98 & UP \\
\hline CGAS & Cyclic GMP-AMP synthase & 1.90 & UP \\
\hline TIFA & TRAF-interacting protein with forkhead-associated domain & 1.85 & UP \\
\hline DHX58 & DExH-box helicase 58 & 1.80 & UP \\
\hline LOC100336669 & Guanylate-binding protein 4 & 1.71 & UP \\
\hline LOC512869 & Ring finger protein 213 -like & 1.67 & UP \\
\hline IRF7 & Interferon regulatory factor 7 & 1.66 & UP \\
\hline XAF1 & XIAP-associated factor 1 & 1.66 & UP \\
\hline$P M L$ & Promyelocytic leukaemia & 1.60 & UP \\
\hline PARPG & Poly(ADP-ribose) polymerase family member 9 & 1.59 & UP \\
\hline LOC616948 & Tripartite motif-containing protein 5-like & 1.59 & UP \\
\hline IFIT5 & Interferon-induced protein with tetratricopeptide repeats 5 & 1.57 & UP \\
\hline SP110 & SP110 nuclear body protein & 1.56 & UP \\
\hline TRIM5 & Tripartite motif-containing 5 & 1.55 & UP \\
\hline PNPT1 & Polyribonucleotide nucleotidyltransferase 1 & 1.44 & UP \\
\hline PARP12 & Poly(ADP-ribose) polymerase family member 12 & 1.37 & UP \\
\hline PARP10 & Poly(ADP-ribose) polymerase family member 10 & 1.30 & UP \\
\hline LOC512486 & Interferon-induced guanylate-binding protein 1 & 1.27 & UP \\
\hline IFI16 & Interferon gamma inducible protein 16 & 1.15 & UP \\
\hline LOC788077 & Histone $\mathrm{H} 3$ & -5.70 & DOWN \\
\hline GFY & Golgi-associated olfactory signalling regulator & -5.71 & DOWN \\
\hline
\end{tabular}


Table 3 Gene ontology (GO) analysis of differentially expressed genes in bovine endometrial explants following co-culture with Day 8 blastocysts for $6 \mathrm{~h}$ (Experiment 1).

\begin{tabular}{|c|c|c|c|c|c|}
\hline GO & Category & Description & Count & $\%$ & $\log 10(P)$ \\
\hline GO:0051607 & GO Biological Processes & Defence response to virus & 26 & 50.98 & -38.24 \\
\hline R-HSA-913531 & Reactome Gene Sets & Interferon signalling & 21 & 41.18 & -29.77 \\
\hline GO:0043900 & GO Biological Processes & Regulation of multi-organism process & 16 & 31.37 & -16.09 \\
\hline R-HSA-1169408 & Reactome Gene Sets & ISG15 antiviral mechanism & 9 & 17.65 & -13.3 \\
\hline GO:0032479 & GO Biological Processes & Regulation of type I interferon production & 10 & 19.61 & -13.25 \\
\hline GO:0060333 & GO Biological Processes & Interferon-gamma-mediated signalling pathway & 8 & 15.69 & -10.58 \\
\hline GO:0050688 & GO Biological Processes & Regulation of defence response to virus & 7 & 13.72 & -9.76 \\
\hline GO:0060760 & GO Biological Processes & Positive regulation of response to cytokine stimulus & 6 & 11.76 & -8.72 \\
\hline GO:0035455 & GO Biological Processes & Response to interferon-alpha & 4 & 7.84 & -6.96 \\
\hline R-HSA-197264 & Reactome Gene Sets & Nicotinamide salvaging & 3 & 5.88 & -4.98 \\
\hline GO:0000209 & GO Biological Processes & Protein polyubiquitination & 6 & 11.76 & -4.68 \\
\hline GO:0045824 & GO Biological Processes & Negative regulation of innate immune response & 3 & 5.88 & -3.81 \\
\hline GO:2000779 & GO Biological Processes & Regulation of double-strand break repair & 3 & 5.88 & -3.36 \\
\hline GO:0050707 & GO Biological Processes & Regulation of cytokine secretion & 4 & 7.84 & -3.21 \\
\hline GO:0030099 & GO Biological Processes & Myeloid cell differentiation & 5 & 9.8 & -2.68 \\
\hline GO:0002244 & GO Biological Processes & Haematopoietic progenitor cell differentiation & 3 & 5.88 & -2.66 \\
\hline GO:0051260 & GO Biological Processes & Protein homo-oligomerisation & 4 & 7.84 & -2.22 \\
\hline GO:0061025 & GO Biological Processes & Membrane fusion & 3 & 5.88 & -2.02 \\
\hline
\end{tabular}

Count refers to the number of genes in the given ontology term. \% is the percentage of all the genes that are found in the given ontology term.

$\log 10(\mathrm{P})$ is the $P$ value in log base 10 .

differential expression of 63 transcripts. Among the most upregulated were RSAD2, MX2, ISG15 and OAS2. Interestingly, two transcripts (Histone H3, Golgiassociated olfactory signalling regulator, GFY) were downregulated. Histone $\mathrm{H} 3$ expression levels have been used as a marker of endometrial proliferation in macaque and human endometrium (Brenner et al. 2003), while, to our knowledge, GFY has not been previously reported as differentially expressed in endometrium. Combining the data from Experiments 1 and 3 (to give a total of ten replicates per group) confirmed the upregulation of 40 transcripts in blastocyst-exposed endometrial explants compared to the control; neither Histone H3 nor GFY was in this list. Comparison of this list of DEG with the common list of genes altered in endometrial explants following culture with $100 \mathrm{ng} / \mathrm{mL}$ IFNT or a Day 15 conceptus (from Sánchez et al. 2019) indicated that all

Table 4 Cleavage rate and blastocyst yield following insemination of in vitro-matured bovine oocytes with X- or Y-sorted spermatozoa (Experiment 2a).

\begin{tabular}{cccc}
\hline & No. oocytes & \% Cleaved & \% Blastocyst \\
\hline Bull 1 & & & \\
$\quad$ X sorted & 439 & $50.2 \pm 5.8$ & $7.6 \pm 3.9$ \\
$\quad$ Y sorted & 415 & $58.6 \pm 5.8$ & $17.2 \pm 3.9$ \\
Bull 2 & & & \\
$\quad$ X sorted & 308 & $75.0 \pm 6.6$ & $10.5 \pm 4.4$ \\
$\quad$ Y sorted & 394 & $70.4 \pm 5.8$ & $18.5 \pm 3.9$ \\
Bull 3 & & & \\
$\quad$ X sorted & 397 & $51.6 \pm 5.8$ & $7.2 \pm 3.9$ \\
Y sorted & 385 & $68.8 \pm 5.8$ & $26.3 \pm 3.9$ \\
Total & & & \\
$\quad$ X sorted & 1144 & $58.9 \pm 4.3$ & $8.4 \pm 2.9^{*}$ \\
$\quad$ Y sorted & 1194 & $65.9 \pm 4.2$ & $20.6 \pm 2.8^{+}$ \\
\hline
\end{tabular}

Five replicates per bull. Values are mean \pm S.E.M.

${ }^{*},+$ Values with different superscripts within the same column differ significantly $(P<0.05)$. the DEG induced in the endometrium by blastocyststage embryos were IFNT stimulated. It is important to note that it was not a forgone conclusion that all the transcripts altered by a blastocyst-stage embryo would be IFNT related. Two recent studies from our group (Mathew et al. 2019, Sánchez et al. 2019) indicate that by Day 15, while the majority of altered endometrial transcripts are IFNT related, a significant number of transcripts are altered in an IFNT-independent manner. Thus, it was, we believe, not unreasonable to hypothesise that some of the changes induced at Day 8 might also be independent of IFNT.

Conceptus-derived IFNT is the primary maternal recognition of pregnancy signal in cattle (reviewed by Bazer \& Thatcher 2017, Forde \& Lonergan 2017) that inhibits upregulation of oxytocin receptors in the endometrial epithelia of the uterus, thereby preventing the production of luteolytic prostaglandin F2 alpha (PGF2 $\alpha$ ) pulses to maintain progesterone production by the corpus luteum (Hansen et al. 2017). In the endometrium, IFNT induces or upregulates a large number of classical ISG and regulates the expression of many other genes in a cell-specific manner that are likely important for conceptus elongation, implantation and establishment of pregnancy (Spencer et al. 2008). Bovine embryos begin to express IFNT upon blastocyst formation (Farin et al. 1990), although there is considerable variation between individual embryos in

Table 5 Verification of blastocyst sex following IVF with X- or Y-sorted sperm and subsequent blastocyst co-culture with bovine endometrial explants for $6 \mathrm{~h}$ (Experiment 2a, 5 replicates).

\begin{tabular}{lccc}
\hline & No. of blastocysts sexed & $\%$ Male $(n)$ & \% Female $(n)$ \\
\hline$X$ sorted & 85 & $5.9(5)$ & $94.1(80)$ \\
$Y$ sorted & 86 & $80.2(69)$ & $19.8(17)$ \\
\hline
\end{tabular}


Table 6 Verification of blastocyst sex following embryo biopsy at Day 6, culture until Day 8 and subsequent blastocyst co-culture with bovine endometrial explants for $6 \mathrm{~h}$ (Experiment $2 \mathrm{~b}, 4$ replicates).

\begin{tabular}{lccccc}
\hline $\begin{array}{l}\text { No. embryos } \\
\text { biopsied on Day } \mathbf{6}\end{array}$ & $\begin{array}{c}\%(n) \text { blastocysts on } \\
\text { Day 8 }\end{array}$ & $\begin{array}{c}\text { No. males based } \\
\text { on biopsy sexing }\end{array}$ & $\begin{array}{c}\%(n) \text { males based on } \\
\text { blastocyst sexing }\end{array}$ & $\begin{array}{c}\text { No. females based } \\
\text { on biopsy sexing }\end{array}$ & $\begin{array}{c}\% \text { (n) females based on } \\
\text { blastocyst sexing }\end{array}$ \\
\hline 355 & $45.1(160)$ & 48 & $95.8(46)$ & 63 & $76.2(48)$ \\
\hline
\end{tabular}

the amount they produce (Hernandez-Ledezma et al. 1992). This variation has been related to the origin of the embryo (Stojkovic et al. 1999), the age at which blastocyst formation occurs (Kubisch et al. 1998, 2001a), the group size in which culture takes place (Larson \& Kubisch 1999), medium composition (Stojkovic et al. 1995, Wrenzycki et al. 1999, Kubisch et al. 2001b, Rizos et al. 2003) and the sex of the embryo (Larson et al. 2001). In contrast, later during preimplantation development, IFNT may not be the only conceptus-derived product which acts on the endometrium. For example, Mamo et al. (2012) described transcripts for conceptus ligands that potentially interact with corresponding receptors on the endometrium during the critical window of maternal recognition of pregnancy. Analysis of the protein content of Day 16 conceptus-conditioned culture medium with uterine luminal fluid (ULF) from cyclic and pregnant heifers on Day 16 identified 30 proteins unique to ULF from pregnant heifers which were also secreted by the conceptus in vitro (Forde et al. 2015). Lastly, comparison of transcripts altered in endometrial explants by the presence of a conceptus compared with those induced by $100 \mathrm{ng} / \mathrm{mL}$ IFNT revealed the altered expression of $>100$ IFNT-independent transcripts in endometrium (Mathew et al. 2019, Sánchez et al. 2019). Later during the preimplantation phase (Days 18-20), the transcriptomic response of the endometrium to pregnancy is quite specific to the type of conceptus present (Al-derived, IVF-derived, cloned) (Bauersachs et al. 2009, Mansouri-Attia et al. 2009), suggesting the endometrium is a biosensor of the developmental competency or origin of the embryo (Sandra et al. 2011).
The aim of Experiment 2 was to investigate sexual dimorphic alterations in the bovine endometrial transcriptome following in vitro exposure to Day 8 male or female blastocysts. The interest in sexual dimorphism is based on the knowledge that one-third of the transcripts present at the blastocyst stage in cattle are regulated by the sex of the embryo (Bermejo-Alvarez et al. 2010a). Consistent with our previous study (Passaro et al. 2018) and data from Experiment 1, in Experiment $2 \mathrm{a}$, we observed an increase in transcript abundance of five ISG (MX1, MX2, ISG15, OASY1, RSAD2) in explants co-cultured with male or female blastocysts produced with sex-sorted semen; however, expression was not affected by embryonic sex. Similarly, in Experiment $2 b$, while transcript abundance for three of the five ISG (MX1, MX2, ISG15) was significantly upregulated by the presence of male or female blastocysts, there were no differences due to embryonic sex. These data are consistent with our previous study in which we failed to detect conceptus-sex-related alterations in the endometrial transcriptome in vivo at the initiation of implantation on Day 19 (Forde et al. 2016). In contrast, Gómez et al. (2013) reported differential protein expression in Day 8 uterine fluid recovered from heifers following the transfer of 60 Day 5 male or female embryos. More recently, Gómez et al. (2018a) described an embryo sex-dependent response of cultured bovine uterine epithelial (but not stromal) cells; single male embryos induced downregulation of SLC2A1, SLC2A5, CTGF, ARTN, IFNAR1 and IFNAR2. While these transcripts were detectable in our dataset, they were not differentially expressed. It is important to note that these authors used cultured epithelial cells rather than
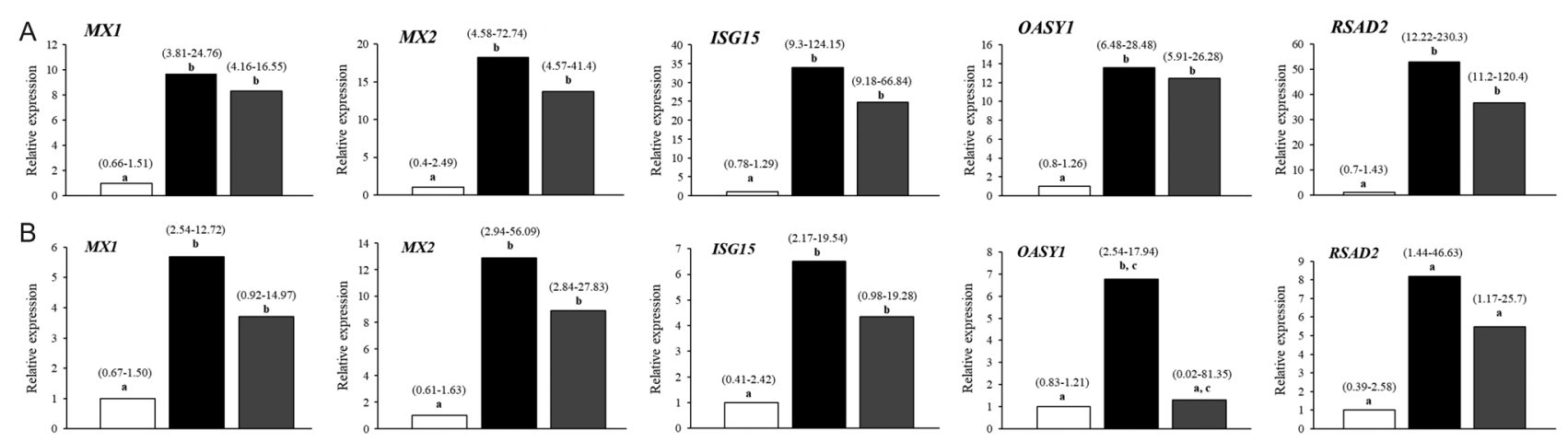

Figure 3 Quantitative real-time PCR analysis of five ISGs candidate genes (MX1, MX2, OAS1Y, ISG15, RSAD2) in bovine endometrial explants following 6-h co-culture with male or female blastocysts produced with sex-sorted semen (A) or by sexed by biopsy prior to culture (B) (Experiment 2). Relative expression values are shown (mean $\pm 95 \%$ confidence interval) for endometrial response to medium alone (Control, white bars); female blastocysts (black bars); male blastocysts (grey bars). Differences in gene expression between treatments $(P<0.01)$ are indicated by different superscript letters $(a, b)$. 

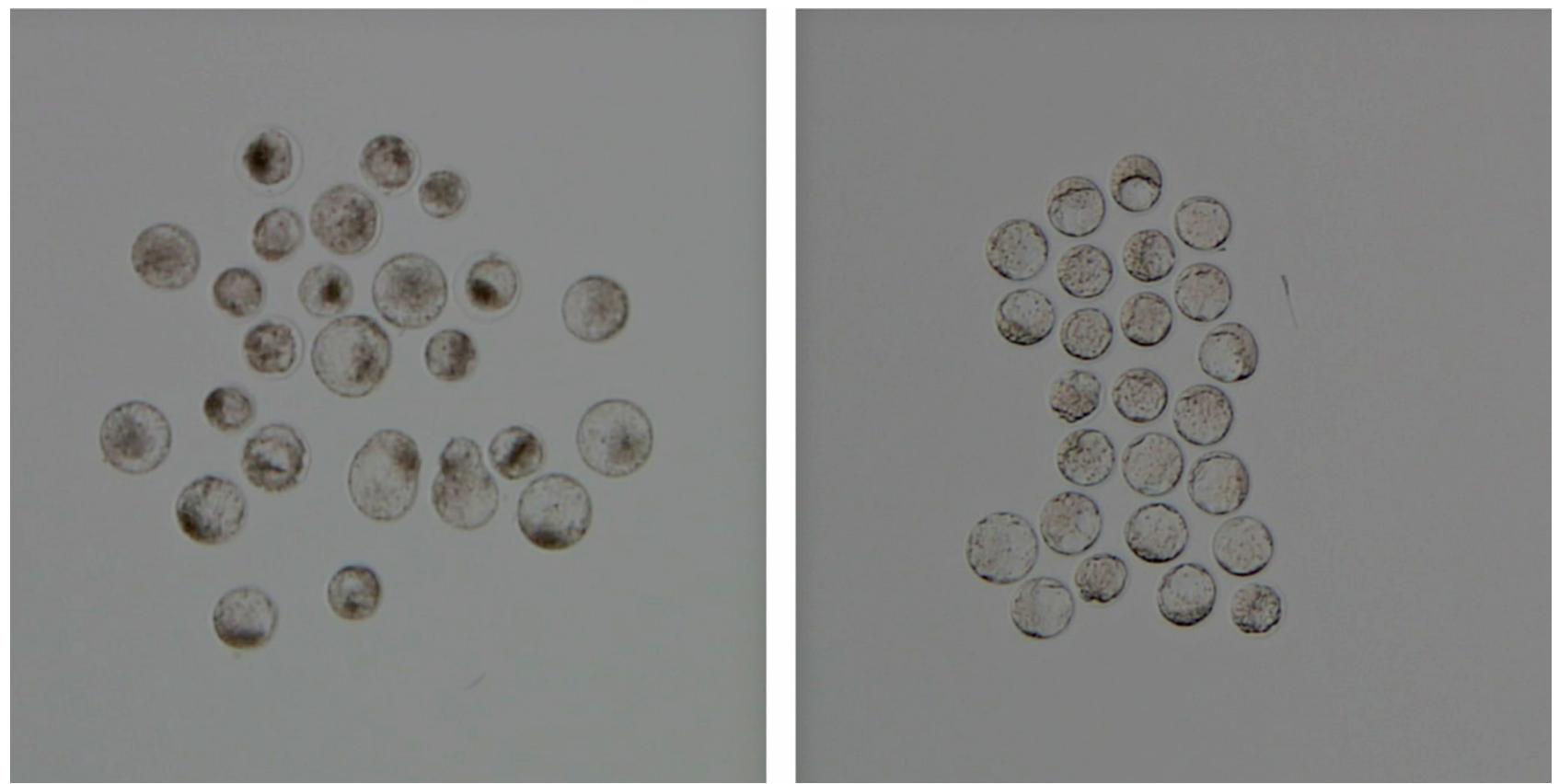

Figure 4 Representative images of bovine (left) and murine (right) blastocysts used for co-culture with bovine endometrial explants (Experiment 3 ).

intact endometrium as used here, and a much longer co-culture period (48vs $6 \mathrm{~h}$ ) which may partly explain the different observations.

Conceptus elongation is a maternally driven process dependent on secretions of the endometrium in vivo; it does not occur in vitro or in vivo in the absence of uterine glands (Gray et al. 2002). Development of bovine embryos to the blastocyst stage is supported by the reproductive tracts of other species following embryo transfer (sheep: Eyestone et al. 1987, Enright et al. 2000) or culture ex vivo (Mouse: Rizos et al. 2010). Indeed, bovine conceptuses will elongate in the ovine uterus (Rexroad \& Powell 1999, Black et al. 2010). However, to what extent elongation is intrinsic to the embryo or whether the endometrium responds differently to embryos destined to elongate (e.g., ruminant, porcine) compared to those that do not elongate (e.g., rodent, primate, equine) is unknown. As a first step to address this intriguing question we tested the hypothesis that murine embryos would elicit a different response from bovine endometrium than bovine embryos. Exposure to murine blastocysts did not induce any detectable changes in transcript abundance in bovine endometrial explants. While this observation is somewhat surprising, it is consistent with our previous observation that the presence of oocytes or embryos up to the morula stage did not induce changes in the expression of candidate ISG (Passaro et al. 2018).

In conclusion, these findings, coupled with our previous data, indicate that very local, IFNT-induced, changes in endometrial gene expression occur in response to blastocysts; whether such changes play any role in subsequent pregnancy recognition remains to be established. We believe the described blastocyst-

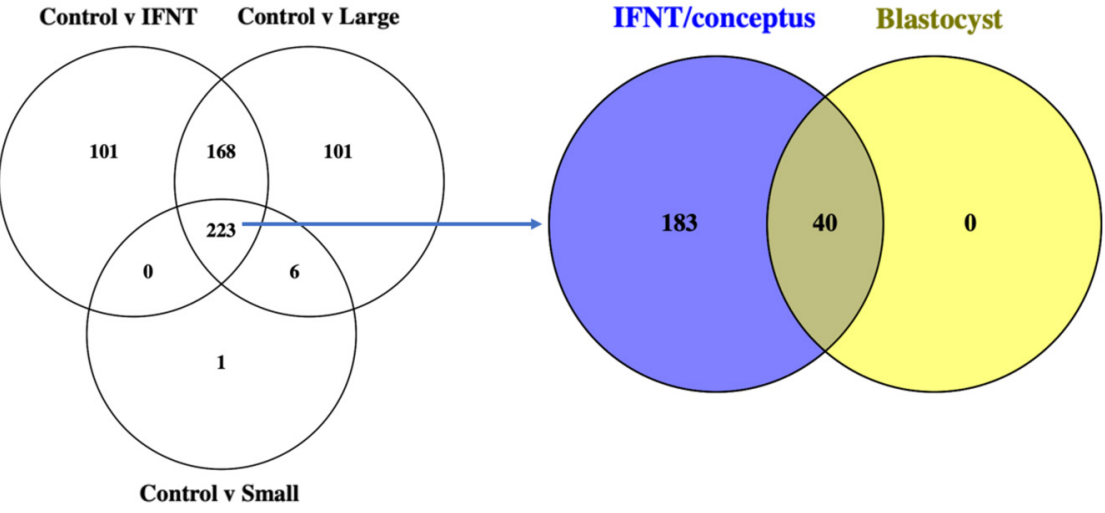

Figure 5 Comparison of list of differentially expressed genes in bovine endometrial explants following 6-h culture with blastocyst stage embryos (right, from the combined analysis of Experiments 1 and 3 in the current study; in yellow) with the common list of transcripts altered in endometrial explants following $6 \mathrm{~h}$ culture with $100 \mathrm{ng} / \mathrm{mL}$ interferon-tau (IFNT) or a Day 15 long or short conceptus (left, from Sánchez et al. 2019; in blue). Data indicate that all the DEG induced in the endometrium by a blastocyst are IFNT related (in contrast to Day 15 when a significant number of IFNT-independent genes are induced (Sánchez et al. 2019)). 
induced alterations in transcript abundance are novel (not shown previously) and solid (based on ten replicates - five from each of two independent experiments in the manuscript). Further validation of these transcripts comes from the fact that they were also detected in an independent study using Day 15 conceptuses (Sánchez et al. 2019). Future studies we may in the future do some proteomic work on these or similar tissues in a much larger study, looking at the expression of one or two proteins here would be somewhat gratuitous and would not add much in our view.

\section{Supplementary data}

This is linked to the online version of the paper at https://doi.org/10.1530/REP-19-0064.

\section{Declaration of interest}

Trudee Fair is a member of the Editorial Board of Reproduction. Trudee Fair was not involved in the review or editorial process for this paper, on which she is listed as an author. The other authors have nothing to disclose.

\section{Funding}

This work was supported by Science Foundation Ireland (13/IA/1983).

\section{Acknowledgements}

The authors thank Mary Wade (UCD) for excellent technical assistance and Dr Constantine Simintiras (UCD) for help in drafting a figure.

\section{References}

Alexopoulos NI, Vajta G, Maddox-Hyttel P, French AJ \& Trounson AO 2005 Stereomicroscopic and histological examination of bovine embryos following extended in vitro culture. Reproduction, Fertility, and Development 17 799-808. (https://doi.org/10.1071/RD04104)

Avery B, Jørgensen CB, Madison V \& Greve T 1992 Morphological development and sex of bovine in vitro-fertilized embryos. Molecular Reproduction and Development 32 265-270. (https://doi.org/10.1002/ mrd.1080320312)

Bauersachs S, Ulbrich SE, Zakhartchenko V, Minten M, Reichenbach M, Reichenbach HD, Blum H, Spencer TE \& Wolf E 2009 The endometrium responds differently to cloned versus fertilized embryos. PNAS 106 5681-5686. (https://doi.org/10.1073/pnas.0811841106)

Bauersachs S, Ulbrich SE, Reichenbach HD, Reichenbach M, Büttner M, Meyer HH, Spencer TE, Minten M, Sax G, Winter G et al. 2012 Comparison of the effects of early pregnancy with human interferon, alpha 2 (IFNA2), on gene expression in bovine endometrium. Biology of Reproduction 86 46. (https://doi.org/10.1095/biolreprod.111.094771)

Bazer FW \& Thatcher WW 2017 Chronicling the discovery of interferon tau. Reproduction 154 F11-F20. (https://doi.org/10.1530/REP-17-0257)

Bermejo-Alvarez P, Rizos D, Rath D, Lonergan P \& Gutierrez-Adan A 2010a Sex determines the expression level of one third of the actively expressed genes in bovine blastocysts. PNAS 107 3394-3399. (https:// doi.org/10.1073/pnas.0913843107)
Bermejo-Alvarez P, Lonergan P, Rath D, Gutiérrez-Adan A \& Rizos D $2010 b$ Developmental kinetics and gene expression in male and female bovine embryos produced in vitro with sex-sorted spermatozoa. Reproduction, Fertility, and Development 22 426-436. (https://doi. org/10.1071/RD09142)

Betteridge KJ, Eaglesome MD, Randall GC \& Mitchell D 1980 Collection, description and transfer of embryos from cattle 10-16 days after oestrus. Journal of Reproduction and Fertility 59 205-216. (https://doi. org/10.1530/jrf.0.0590205)

Black SG, Arnaud F, Burghardt RC, Satterfield MC, Fleming JA, Long CR, Hanna C, Murphy L, Biek R, Palmarini M et al. 2010 Viral particles of endogenous betaretroviruses are released in the sheep uterus and infect the conceptus trophectoderm in a transspecies embryo transfer model. Journal of Virology 84 9078-9085. (https://doi.org/10.1128/JVI.00950-10)

Blomberg LA, Schreier L \& Li RW 2010 Characteristics of peri-implantation porcine concepti population and maternal milieu influence the transcriptome profile. Molecular Reproduction and Development 77 978-989. (https://doi.org/10.1002/mrd.21253)

Brandão DO, Maddox-Hyttel P, Løvendahl P, Rumpf R, Stringfellow D \& Callesen H 2004 Post hatching development: a novel system for extended in vitro culture of bovine embryos. Biology of Reproduction 71 2048-2055. (https://doi.org/10.1095/biolreprod.103.025916)

Brenner RM, Slayden OD, Rodgers WH, Critchley HO, Carroll R, Nie XJ \& Mah K 2003 Immunocytochemical assessment of mitotic activity with an antibody to phosphorylated histone $\mathrm{H} 3$ in the macaque and human endometrium. Human Reproduction 18 1185-1193. (https://doi. org/10.1093/humrep/deg255)

Cha JM \& Dey SK 2015 Reflections on rodent implantation. Advances in Anatomy, Embryology, and Cell Biology 216 69-85. (https://doi. org/10.1007/978-3-319-15856-3_5)

Clemente $M$, de La Fuente J, Fair T, Al Naib A, Gutierrez-Adan A, Roche JF, Rizos D \& Lonergan P 2009 Progesterone and conceptus elongation in cattle: a direct effect on the embryo or an indirect effect via the endometrium? Reproduction 138 507-517. (https://doi.org/10.1530/ REP-09-0152)

Cohen J 1960 A coefficient of agreement for nominal scales. Educational and Psychological Measurement 20 37-46. (https://doi. org/10.1177/001316446002000104)

Enright BP, Lonergan P, Dinnyes A, Fair T, Ward FA, Yang X \& Boland MP 2000 Culture of in vitro produced bovine zygotes in vitro vs in vivo: implications for early embryo development and quality. Theriogenology 54 659-673. (https://doi.org/10.1016/S0093-691X(00)00381-2)

Eyestone WH, Leibfried-Rutledge ML, Northey DL, Gilligan BG \& First NL 1987 Culture of one- and two-cell bovine embryos to the blastocyst stage in the ovine oviduct. Theriogenology 28 1-7. (https:// doi.org/10.1016/0093-691X(87)90179-8)

Farin CE, Imakawa K, Hansen TR, McDonnell JJ, Murphy CN, Farin PW \& Roberts RM 1990 Expression of trophoblastic interferon genes in sheep and cattle. Biology of Reproduction 43 210-218. (https://doi. org/10.1095/biolreprod43.2.210)

Forde N \& Lonergan P 2017 Interferon-tau and fertility in ruminants. Reproduction 154 F33-F43. (https://doi.org/10.1530/REP-17-0432)

Forde N, Carter F, Spencer TE, Bazer FW, Sandra O, Mansouri-Attia N, Okumu LA, McGettigan PA, Mehta JP, McBride R et al. 2011 Conceptusinduced changes in the endometrial transcriptome: how soon does the cow know she is pregnant? Biology of Reproduction 85 144-156. (https://doi.org/10.1095/biolreprod.110.090019)

Forde N, Bazer FW, Spencer TE \& Lonergan P 2015 'Conceptualizing' the endometrium: identification of conceptus-derived proteins during early pregnancy in cattle. Biology of Reproduction 92 156. (https://doi. org/10.1095/biolreprod.115.129296)

Forde N, Maillo V, O'Gaora P, Simintiras CA, Sturmey RG, Ealy AD, Spencer TE, Gutierrez-Adan A, Rizos D \& Lonergan P 2016 Sexually dimorphic gene expression in bovine conceptuses at the initiation of implantation. Biology of Reproduction 95 92. (https://doi.org/10.1095/ biolreprod.116.139857)

Gómez E, Caamaño JN, Corrales FJ, Díez C, Correia-Álvarez E, Martín D, Trigal B, Carrocera S, Mora MI, Pello-Palma J et al. 2013 Embryonic sex induces differential expression of proteins in bovine uterine fluid. Journal of Proteome Research 12 1199-1210. (https://doi.org/10.1021/ pr300845e) 
Gómez E, Sánchez-Calabuig MJ, Martin D, Carrocera S, Murillo A, Correia-Alvarez E, Herrero $P$, Canela N, Gutiérrez-Adán A, Ulbrich $S$ et al. 2018 a In vitro cultured bovine endometrial cells recognize embryonic sex. Theriogenology 108 176-184. (https://doi.org/10.1016/j. theriogenology.2017.11.038)

Gómez E, Carrocera S, Martin D, Herrero P, Canela N \& Muñoz M 2018 b Differential release of cell-signaling metabolites by male and female bovine embryos cultured in vitro. Theriogenology 114 180-184. (https:// doi.org/10.1016/j.theriogenology.2018.03.038)

Gray CA, Burghardt RC, Johnson GA, Bazer FW \& Spencer TE 2002 Evidence that absence of endometrial gland secretions in uterine gland knockout ewes compromises conceptus survival and elongation. Reproduction 124 289-300. (https://doi.org/10.1530/rep.0.1240289)

Hansen PJ, Dobbs KB, Denicol AC \& Siqueira LGB 2016 Sex and the preimplantation embryo: implications of sexual dimorphism in the preimplantation period for maternal programming of embryonic development. Cell and Tissue Research 363 237-247. (https://doi. org/10.1007/s00441-015-2287-4)

Hansen TR, Sinedino LDP \& Spencer TE 2017 Paracrine and endocrine actions of interferon tau (IFNT). Reproduction 154 F45-F59. (https://doi. org/10.1530/REP-17-0315)

Hernandez-Ledezma JJ, Sikes JD, Murphy CN, Watson AJ, Schultz GA \& Roberts RM 1992 Expression of bovine trophoblast interferon in conceptuses derived by in vitro techniques. Biology of Reproduction 47 374-380. (https://doi.org/10.1095/biolreprod47.3.374)

Hochberg Y \& Benjamini Y 1990 More powerful procedures for multiple significance testing. Statistics in Medicine 9 811-818. (https://doi. org/10.1002/sim.4780090710)

Ireland JJ, Murphee RL \& Coulson PB 1980 Accuracy of predicting stages of bovine estrous cycle by gross appearance of the corpus luteum. Journal of Dairy Science 63 155-160. (https://doi.org/10.3168/jds. S0022-0302(80)82901-8)

Kubisch HM, Larson MA \& Roberts RM 1998 Relationship between age of blastocyst formation and interferon-tau secretion by in vitroderived bovine embryos. Molecular Reproduction and Development 49 254-260. 2795(199803)49:3<254::AID-MRD5>3.0.CO;2-N)

Kubisch HM, Larson MA \& Kiesling DO 2001a Control of interferontau secretion by in vitro-derived bovine blastocysts during extended culture and outgrowth formation. Molecular Reproduction and Development 58 390-397. (https://doi.org/10.1002/10982795(20010401)58:4<390::AID-MRD6>3.0.CO;2-V)

Kubisch HM, Larson MA, Ealy AD, Murphy CN \& Roberts RM 2001b Genetic and environmental determinants of interferon-tau secretion by in vivo- and in vitro-derived bovine blastocysts. Animal Reproduction Science 66 1-13. (https://doi.org/10.1016/S0378-4320(01)00086-0)

Larson MA \& Kubisch HM 1999 The effects of group size on development and interferon-tau secretion by in-vitro fertilized and cultured bovine blastocysts. Human Reproduction 14 2075-2079. (https://doi. org/10.1093/humrep/14.8.2075)

Larson MA, Kimura K, Kubisch HM \& Roberts RM 2001 Sexual dimorphism among bovine embryos in their ability to make the transition to expanded blastocyst and in the expression of the signaling molecule IFN-tau. PNAS 98 9677-9682. (https://doi.org/10.1073/pnas.171305398)

Lonergan P \& Forde N 2014 Maternal-embryo interaction leading up to the initiation of implantation of pregnancy in cattle. Animal 8 (Supplement 1) 64-69. (https://doi.org/10.1017/S1751731114000470)

Mamo S, Mehta JP, Forde N, McGettigan P \& Lonergan P 2012 Conceptusendometrium crosstalk during maternal recognition of pregnancy in cattle. Biology of Reproduction 87 6, 1-6, 9. (https://doi.org/10.1095/ biolreprod.112.099945)

Mansouri-Attia N, Sandra O, Aubert J, Degrelle S, Everts RE, GiraudDelville C, Heyman Y, Galio L, Hue I, Yang X et al. 2009 Endometrium as an early sensor of in vitro embryo manipulation technologies. PNAS 106 5687-5692. (https://doi.org/10.1073/pnas.0812722106)

Mathew DJ, Sánchez JM, Passaro C, Charpigny G, Behura SK, Spencer TE \& Lonergan P 2019 Title: interferon tau-dependent and independent effects of the bovine conceptus on the endometrial transcriptome. Biology of Reproduction 100 365-380. (https://doi.org/10.1093/biolre/ ioy 199)

Moraes JGN, Behura SK, Geary TW, Hansen PJ, Neibergs HL \& Spencer TE 2018 Uterine influences on conceptus development in fertility- classified animals. PNAS 115 E1749-E1758. (https://doi.org/10.1073/ pnas.1721191115)

Oliveira CS, Saraiva NZ, de Souza MM, Tetzner TAD, de Lima MR \& Garcia JM 2010 Effects of histone hyperacetylation on the preimplantation development of male and female bovine embryos. Reproduction, Fertility, and Development 22 1041-1048. (https://doi. org/10.1071/RD09238)

Park JH, Lee JH, Choi KM, Joung SY, Kim JY, Chung GM, Jin DI \& Im KS 2001 Rapid sexing of preimplantation bovine embryo using consecutive and multiplex polymerase chain reaction (PCR) with biopsied single blastomere. Theriogenology 55 1843-1853. (https://doi.org/10.1016/ S0093-691X(01)00526-X)

Passaro C, Tutt D, Mathew DJ, Sánchez JM, Browne JA, Boe-Hansen GB, Fair T \& Lonergan P 2018 Blastocyst-induced changes in the bovine endometrial transcriptome. Reproduction 156 219-229. (https://doi. org/10.1530/REP-18-0188)

Rexroad CE \& Powell AM 1999 The ovine uterus as a host for in vitroproduced bovine embryos. Theriogenology 52 351-364. (https://doi. org/10.1016/S0093-691X(99)00134-X)

Rizos D, Ward F, Duffy P, Boland MP \& Lonergan P 2002 Consequences of bovine oocyte maturation, fertilization or early embryo development in vitro versus in vivo: implications for blastocyst yield and blastocyst quality. Molecular Reproduction and Development 61 234-248. (https:// doi.org/10.1002/mrd.1153)

Rizos D, Gutiérrez-Adán A, Pérez-Garnelo S, De La Fuente J, Boland MP \& Lonergan P 2003 Bovine embryo culture in the presence or absence of serum: implications for blastocyst development, cryotolerance, and messenger RNA expression. Biology of Reproduction 68 236-243. (https://doi.org/10.1095/biolreprod.102.007799)

Rizos D, Ramirez MA, Pintado B, Lonergan P \& Gutierrez-Adan A 2010 Culture of bovine embryos in intermediate host oviducts with emphasis on the isolated mouse oviduct. Theriogenology 73 777-785. (https://doi. org/10.1016/j.theriogenology.2009.10.001)

Sánchez JM, Mathew DJ, Behura SK, Passaro C, Charpigny G, Butler ST, Spencer TE \& Lonergan P 2019 Bovine endometrium responds differentially to age-matched short and long conceptuses. Biology of ReproductionEpub. (https://doi.org/10.1093/biolre/ioz060).

Sandra O, Mansouri-Attia N \& Lea RG 2011 Novel aspects of endometrial function: a biological sensor of embryo quality and driver of pregnancy success. Reproduction, Fertility, and Development 24 68-79. (https://doi. org/10.1071/RD11908)

Spencer TE, Sandra O \& Wolf E 2008 Genes involved in conceptusendometrial interactions in ruminants: insights from reductionism and thoughts on holistic approaches. Reproduction 135 165-179. (https:// doi.org/10.1530/REP-07-0327)

Spencer TE, Forde N \& Lonergan P 2016 Insights into conceptus elongation and establishment of pregnancy in ruminants. Reproduction, Fertility, and Development 29 84-100. (https://doi.org/10.1071/RD16359)

Sponchiado M, Gomes NS, Fontes PK, Martins T, Del Collado M, Pastore AA, Pugliesi G, Nogueira MFG \& Binelli M 2017 Pre-hatching embryo-dependent and -independent programming of endometrial function in cattle. PLOS ONE 12 e0175954. (https://doi.org/10.1371/ journal.pone.0175954)

Stojkovic M, Wolf E, Büttner M, Berg U, Charpigny G, Schmitt A \& Brem G 1995 Secretion of biologically active interferon tau by in vitro-derived bovine trophoblastic tissue. Biology of Reproduction 53 1500-1507. (https://doi.org/10.1095/biolreprod53.6.1500)

Stojkovic M, Büttner M, Zakhartchenko V, Riedl J, Reichenbach HD, Wenigerkind H, Brem G \& Wolf E 1999 Secretion of interferon-tau by bovine embryos in long-term culture: comparison of in vivo derived, in vitro produced, nuclear transfer and demi-embryos. Animal Reproduction Science 55 151-162. (https://doi.org/10.1016/S0378-4320(99)00015-9)

Su RW \& Fazleabas AT 2015 Implantation and establishment of pregnancy in human and nonhuman primates. Advances in Anatomy, Embryology, and Cell Biology 216 189-213. (https://doi.org/10.1007/978-3-31915856-3_10)

Talukder AK, Yousef MS, Rashid MB, Awai K, Acosta TJ, Shimizu T, Okuda K, Shimada M, Imakawa K \& Miyamoto A 2017 Bovine embryo induces an anti-inflammatory response in uterine epithelial cells and immune cells in vitro: possible involvement of interferon tau as an intermediator. Journal of Reproduction and Development 63 425-434. (https://doi.org/10.1262/jrd.2017-056) 
Tiffin GJ, Rieger D, Betteridge KJ, Yadav BR \& King WA 1991 Glucose and glutamine metabolism in pre-attachment cattle embryos in relation to sex and stage of development. Journal of Reproduction and Fertility 93 125-132. (https://doi.org/10.1530/jrf.0.0930125)

Tominaga K \& Hamada Y 2004 Efficient production of sex-identified and cryosurvived bovine in-vitro produced blastocysts. Theriogenology 61 1181-1191. (https://doi.org/10.1016/j.theriogenology.2003.07.008)

Vandesompele J, De Preter K, Pattyn F, Poppe B, Van Roy N, De Paepe A \& Speleman F 2002 Accurate normalization of real-time quantitative RT-PCR data by geometric averaging of multiple internal control genes. Genome Biology 3 RESEARCH0034. (https://doi.org/10.1186/gb-20023-7-research0034)

Wrenzycki C, Herrmann D, Carnwath JW \& Niemann H 1999 Alterations in the relative abundance of gene transcripts in preimplantation bovine embryos cultured in medium supplemented with either serum or PVA. Molecular Reproduction and Development 53 8-18. (https://doi. org/10.1002/(SICl)1098-2795(199905)53:1<8::AID-MRD2>3.0.CO;2-K)
Xu KP, Yadav BR, King WA \& Betteridge KJ 1992 Sex-related differences in developmental rates of bovine embryos produced and cultured in vitro. Molecular Reproduction and Development 31 249-252. (https://doi. org/10.1002/mrd.1080310404)

Zar JH 1999 Biostatistical Analysis, 4th ed. India: Pearson Education.

Zhou X, Lindsay H \& Robinson MD 2014 Robustly detecting differential expression in RNA sequencing data using observation weights. Nucleic Acids Research 42 e91. (https://doi.org/10.1093/nar/gku310)

Received 12 February 2019

First decision 19 March 2019

Revised manuscript received 13 May 2019

Accepted 18 June 2019 